\title{
Child hearing health: practice of the Family Health Strategy nurses*
}

\author{
SAÚDE AUDITIVA INFANTIL: PRÁTICA DOS ENFERMEIROS DA ESTRATÉGIA SAÚDE \\ DA FAMÍLIA
}

\section{SALUD AUDITIVA INFANTIL: PRÁCTICA DE LOS ENFERMEROS DE LA ESTRATEGIA SALUD DE LA FAMILIA}

\section{Suelen Brito Azevedo', Luciana Pedrosa Leal' ${ }^{2}$ Maria Luiza Lopes Timóteo Lima ${ }^{3}$, Silvana Maria Sobral Griz $^{4}$}

\section{ABSTRACT}

Objective: Evaluating the practice of nurses of the Family Health Strategy (FHS) in child hearing health care. Method: A normative assessment of structure and process, with 37 nurses in the Family Health Units, in the city of Recife, Pernambuco. The data collection instrument originated from the logical model of child hearing health care provided by nurses of the Family Health Strategy, and the matrix of indicators for evaluation of nursing practice. Results: All the nurses identified the hearing developmental milestones. At least two risk factors were identified by $94.5 \%$ of the nurses, and $21.6 \%$ of them carried out educational activities. Conclusion: The normative assessment was considered adequate despite existing limitations in the structure and process.

\section{RESUMO}

Avaliar a prática dos enfermeiros da Estratégia Saúde da Família na atenção à saúde auditiva infantil. Método: Avaliação normativa, da estrutura e processo, com 37 enfermeiros nas Unidades de Saúde da Família, no município de Recife, Pernambuco. $O$ instrumento de coleta de dados originou-se do modelo lógico da atenção à saúde auditiva infantil prestada pelo enfermeiro da Estratégia Saúde da Família e da matriz de indicadores para avaliação da prática dos enfermeiros. Resultados: Todos os enfermeiros identificaram os marcos do desenvolvimento auditivo, $94,5 \%$, pelo menos, dois fatores de risco, e $21,6 \%$ realizaram atividades educativas. Conclusão: $A$ avaliação normativa foi considerada adequada apesar de haver limitações na estrutura e no processo.

\section{DESCRITORES}

Criança

Perda auditiva

Desenvolvimento infantil

Enfermagem pediátrica

Estratégia Saúde a Família

\section{RESUMEN}

Objetivo: Evaluar la práctica de los enfermeros de la Estrategia Salud de la Familia en la atención a la salud auditiva infantil. Método: Evaluación normativa de la estructura y el proceso, con 37 enfermeros en las Unidades de Salud de la Familia del municipio de Recife, Pernambuco. El instrumento de recolección de datos se originó del modelo lógico de la atención a la salud auditiva infantil prestada por el enfermero de la Estrategia Salud de la Familia y la matriz de indicadores para evaluación de la práctica de los enfermeros. Resultados: Todos los enfermeros identificaron los marcos del desarrollo auditivo, el 94,5\%, por lo menos, dos factores de riesgo, y el $21,6 \%$ realizaron actividades educativas. Conclusión: La evaluación normativa fue considerada adecuada a pesar de haber limitaciones en la estructura y el procedimiento.

\author{
DESCRIPTORES \\ Niño \\ Pérdida auditiva \\ Desarrollo infantil \\ Enfermería pediátrica \\ Estrategia de Salud Familiar.
}

\footnotetext{
* Extracted from the dissertation "Prática dos enfermeiros na atenção à saúde auditiva infantil", Post-Graduate Program in Nursing, Universidade Federal Pernambuco, 2014. ${ }^{1}$ MSc, Post-Graduate Program in Nursing, Center for Health Sciences, Universidade Federal de Pernambuco, Recife, PE, Brazil. ${ }^{2}$ Adjunct Professor, Department of Nursing and of the Post-Graduate Program in Nursing, Center for Health Sciences, Universidade Federal de Pernambuco, Recife, PE, Brazil. ${ }^{3}$ Professor of Speech Pathology and of the Post-Graduate Program in Human Communication Health, Center for Health Sciences, Universidade Federal de Pernambuco, Recife, PE, Brazil. ${ }^{4}$ Adjunct Professor, Department of Speech Pathology and of the Post-Graduate Program in Nursing, Center for Health Sciences, Universidade Federal Pernambuco, Recife, PE, Brazil.
} 


\section{INTRODUCTION}

In 2004, the World Health Organization (WHO) estimated that more than 275 million people worldwide suffered from hearing loss ${ }^{(1)}$. In Brazil, were registered approximately 9.7 million people with some type of hearing loss, constituting $5 \%$ of the population ${ }^{(2)}$. Hearing has its development peak in the early childhood, which is the ideal phase for the identification and intervention of hearing loss ${ }^{(3)}$.

Hearing loss may be associated with risk factors, namely: family history, congenital and postnatal infections, craniofacial anomalies and trauma, hyperbilirubinemia, ototoxic medications, prematurity, low birth weight, anoxia, low Apgar scores, consanguinity, length of stay in the Neonatal Intensive Care Unit (NICU), mechanical ventilation, various syndromes, maternal diabetes, lack of antenatal care $^{(4-5)}$.

The detection of hearing loss during childhood allows the diagnosis before three months of age and intervention before six months ${ }^{(6)}$. The Universal Newborn Hearing Screening (UNHS), known as the otoacoustic emission test (OAE)/automated auditory brainstem response (AABR) or, in Portuguese teste da orelhinha, is the screening test for diagnosis of hearing loss, and should be done before the newborn's discharge from hospital ${ }^{(7)}$.

The ordinance nr. 587/2004, which establishes the National Policy on Hearing Health Care, discusses the actions of hearing health in primary care and in medium and high complexity services by determining the necessary technical quality for the proper performance of each level of attention $^{(8-9)}$. The Family Health Strategy (FHS) is inserted in this context, with the development of actions for promoting, protecting and recovering health through a multidisciplinary team ${ }^{(10)}$.

In their actions developed during the child health care consultation, the nurses shall evaluate the evolution of the child developmental milestones, including the hearing aspects, which are in the development surveillance instrument proposed by the Ministry of Health ${ }^{(11-12)}$. This instrument is available in the child health booklet and guides the systematic process of evaluating the child development by age group, and the decision-making of professionals with data from any of the diagnostic impressions: probable developmental delay; alert for the development; normal development with risk factors; or normal development ${ }^{(11-12)}$.

The actions of nurses for promoting child hearing development begin in the monitoring of pregnant women in low risk prenatal, since the response of the fetus to auditory stimulation begins after the $20^{\text {th }}$ week of gestation ${ }^{(13)}$. Other actions directed to child hearing health can be developed through health education to the family and other actors involved in the social context of the child. The pro- per nursing practice in child care, including child hearing health, may decrease the effects of hearing loss.

The assessment of adequacy will allow a reflection on the knowledge and the work process of nurses regarding the hearing health care of children under two years old. The aim of this study was to evaluate the practice of nurses of the Family Health Strategy in the care to children's hearing health.

\section{METHOD}

A normative assessment was carried out, measuring interventions by comparisons of structure, process and/ or results, with predetermined standards ${ }^{(14)}$. In this study the structure and the process were evaluated, which covers the resources used and the activities, goods and services provided by the FHS nurses. The study was carried out in 36 out of 38 Family Health Units (FHU) of the Health District IV, which covers 12 districts divided into three micro areas, in the city of Recife, Pernambuco. Data collection was done with 37 of the 40 nurses of the Family Health Teams, between August and October 2013. Two nurses did not participate in the study because of the difficulty of contact after three attempts, and one was in medical leave.

The data collection instrument was originated from the logical model of child hearing health care provided by FSH nurses and the matrix of indicators for evaluating this practice. The logical model explains the activities operation, and the associated causes ${ }^{(14)}$. It was prepared according to the following: the National Policy on Hearing Health Care (Ordinance nrs. 2073 and 587/2004) ${ }^{(8-9)}$; the report of the Joint Committee on Infant Hearing ${ }^{(5-6)}$, the National Primary Care Policy ${ }^{(10)}$; the neonatal Manual of Integrated Management of Childhood IIIness (IMCI)(15) and the Child Health Booklet (surveillance instrument of development) $)^{(11-12)}$.

The logic model includes the structure in the dimension of physical structure/needed materials and the process, in the dimensions of technical-scientific adequacy and professional training (Figure 1). The indicator matrix was elaborated consisting of quantitative factors expressed through expected scores, which are interconnected to the criteria used to measure the components of an intervention $^{(14)}$.

In the indicators matrix, the score was subdivided into 40 points for the dimension of physical structure/needed materials, and 60 points for the dimensions of technicalscientific adequacy and professional training, totaling 100 points. In the dimension of physical structure/needed materials, the score was divided among the nine indicators obtaining 4.4 points/indicator. In the dimension of technical-scientific adequacy and professional training, 40 points were divided among 13 indicators, resulting in 3.1
Child hearing health: practice of the Family Health Strategy nurses

Azevedo SB, Leal LP, Lima MLLT, Griz SMS 
points/indicator. In the dimension of technical-scientific adequacy, the indicator of nurses' conduct in face of four clinical cases obtained a score of 5.0 points for every correct conduct, totaling 20 points. The four clinical cases are described below:

Case 1 - reported an infant with a risk factor for hearing loss and hearing developmental milestone incompatible with age, in which the conduct would be referral to other professionals for assessment and guide the caregiver on the importance of the referral.

Case 2 - described an infant with a risk factor for hearing loss and developmental milestones compatible for age, where the conduct was to guide the caregiver about the signs of alert and reassess the infant in $\mathbf{3 0}$ days.

Case 3 - reported an infant who had no risk factors for hearing loss and developmental milestones consistent with age, in which the conduct was to guide the caregiver to stimulate the child and reschedule the next routine appointment.

Case 4 -described an infant with risk factors for hearing loss and auditory development milestones incompatible for age, where the conduct was the referral to neuropsychomotor assessment and guidance of the caregiver on the importance of the referral.

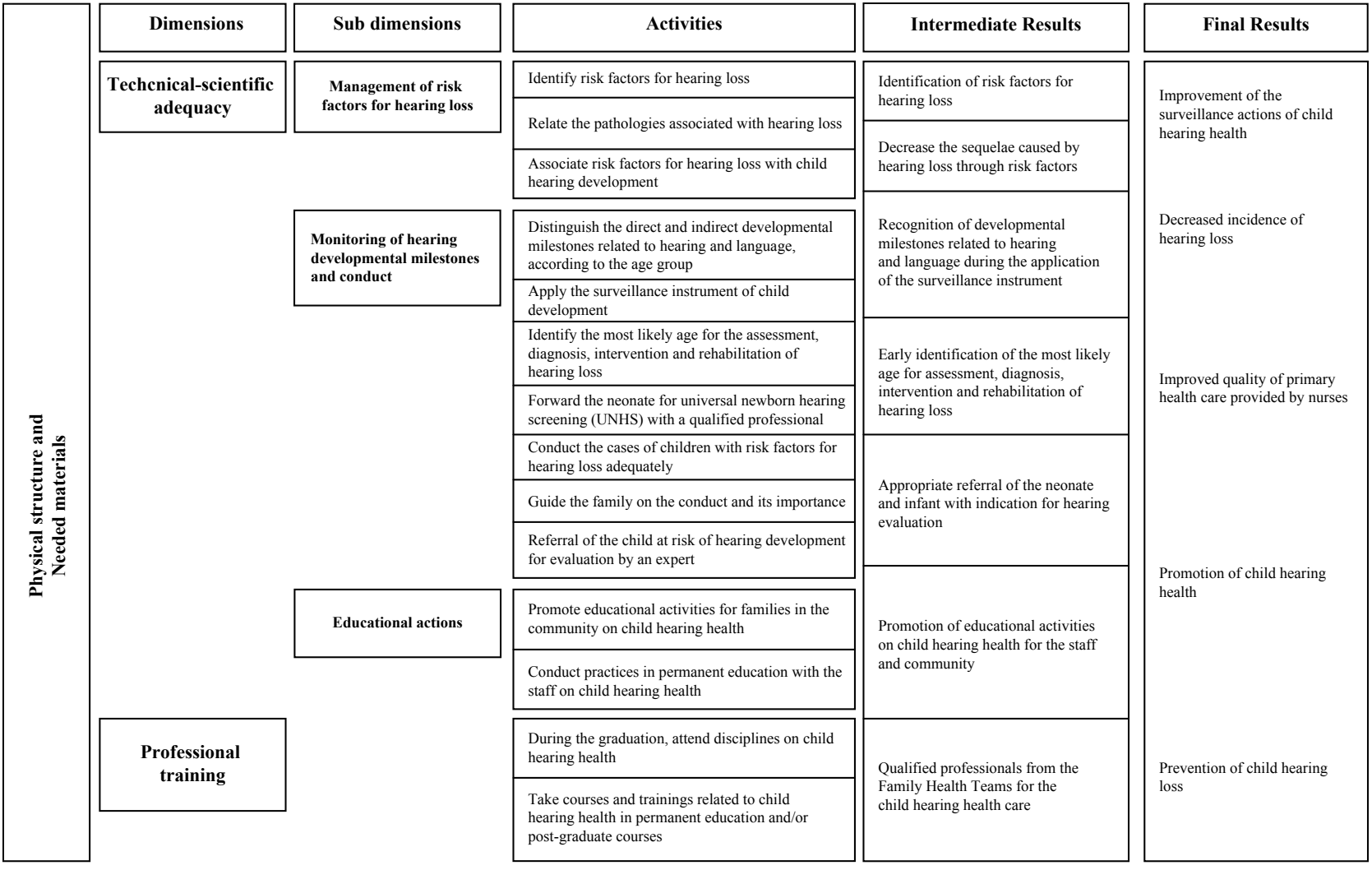

Figure 1 - Logical model of child hearing health care provided by the FHS nurse - Recife, PE, 2012.

The matrix of indicators was subjected to semantic and content validity with experts in the field of speech therapy and nursing. The data collection instrument was produced after the validation process of the matrix of assessment. The instrument for data collection was applied through an interview previously arranged with each nurse, when was also given the informed consent with clarification on the purpose of the study.

The data were analyzed based on the score described in the matrix of indicators. After obtaining the scores of each evaluated dimension (physical structure and needed materials, technical-scientific adequacy and professional training), the nursing practice in the child hearing health care was classified into strata adapted from the study by
Samico ${ }^{(14)}$ : inadequate ( 1 to $<25$ points); partially inadequate ( 25 to $<50$ points); partially adequate (50 to $<75$ points) and adequate (75 to 100 points).

Data were processed and analyzed using the Statistical Package for the Social Sciences (SPSS), version 21.0. The Chisquare test was applied to compare the proportions in frequency distributions. The Student's t-test was applied to compare the mean scores between two groups, and for three or more groups was used the analysis of variance (ANOVA). The confidence interval was $95 \%$ and the significance level $p<0.05$. The study was approved by the Ethics and Research Committee of the Universidade Federal de Pernambuco (UFPE), under CAAE nr. 14818613.0.0000.5208, following the norms by the Resolution 466/2012 of the National Health Council. 


\section{RESULTS}

Most nurses were female (35 cases, 94.6\%), with a mean age of 40.5 years (standard deviation, SD $=8.0$ ). Regarding the time since graduation, there was the same proportion of nurses (13 cases, 35.1\%) with between zero and 10 years and those with more than 20 years. Regarding academic titles, 29 nurses (78.4\%) declared themselves specilists, and on the operating time in the FHS, 17 nurses (46\%) worked for more than ten years. With regard to employment status, 27 nurses (73\%) had other engagements and of these, 21 (56.8\%) worked in public hospitals.

As for the physical structure of the family health units (FHU), the less evident indicators were the existence of instruments for sound emission (30.6\%) and informational material (5.6\%). Although most of the FHU have physical space intended for educational activities (91.7\%), many of them used the waiting room for this purpose (Table 1).

Table 1 - Physical structure of the family health units of the Sanitary District IV - Recife, 2013.

\begin{tabular}{|c|c|c|c|c|c|c|c|c|}
\hline \multirow{2}{*}{ Physical space and needed materials } & \multicolumn{2}{|c|}{ Micro area 1} & \multicolumn{2}{|c|}{ Micro area 2} & \multicolumn{2}{|c|}{ Micro area 3} & \multicolumn{2}{|c|}{ Sanitary district IV } \\
\hline & $n=14$ & $\%$ & $\mathbf{n}=\mathbf{0 7}$ & $\%$ & $n=15$ & $\%$ & $n=36$ & $\%$ \\
\hline Room for consultation & 14 & 100.0 & 07 & 100.0 & 15 & 100.0 & 36 & 100.0 \\
\hline Space for educational activities & 14 & 100.0 & 06 & 85.7 & 13 & 86.7 & 33 & 91.7 \\
\hline Table/ chairs/ bed/gurney/exam table & 14 & 100.0 & 07 & 100.0 & 15 & 100.0 & 36 & 100.0 \\
\hline Instruments used for emission of sound & 04 & 28.6 & 04 & 57.1 & 03 & 20.0 & 11 & 30.6 \\
\hline Child health booklet & 14 & 100.0 & 07 & 100.0 & 15 & 100.0 & 36 & 100.0 \\
\hline Registration card/child medical record & 14 & 100.0 & 07 & 100.0 & 15 & 100.0 & 36 & 100.0 \\
\hline Informational materials & 00 & 0.0 & 00 & 0.0 & 02 & 13.3 & 02 & 5.6 \\
\hline
\end{tabular}

Most nurses responded appropriately to clinical cases, with a mean score of $16.5(10-20$ points / SD $=2.9)$. In the sub dimension of educational activities, among the eight nurses (21.6\%) who performed activities targeted for the child hearing health, five (13.5\%) did it individually during the child care consultation, and three (8.1\%) did it collectively, in a group of pregnant women or of mothers with children (Table 2).

In the dimension of professional training, eight (21.6\%) nurses reported having attended some discipline with content related to child hearing health during the undergraduate and/or post-graduate course. However, on courses and/or trainings directed to this subject, only three $(8.1 \%)$ reported having previously participated (Table 2). Among the 11 (29.7\%) nurses who had obtained some information on child hearing health, five (13.5\%) received it during post-graduate courses, four (10.8\%) in the nursing undergraduate course, one $(2.7 \%)$ in courses or trainings, and one $(2.7 \%)$ in the Support Center for Family Health (NASF - Núcleo de Apoio à Saúde da Família). It is noteworthy that $26(70.3 \%)$ nurses did not have any information related to child hearing health.

Table 2 - Technical-scientific adequacy and professional training of nurses in the Sanitary District IV - Recife-PE, 2013

\begin{tabular}{|c|c|c|c|c|}
\hline Dimension & Sub dimensions & Addressed criteria & Value $\mathbf{n}=\mathbf{3 7}$ & $\begin{array}{c}\text { Total value } \\
\%\end{array}$ \\
\hline \multirow{14}{*}{$\begin{array}{l}\text { Technical-scientific } \\
\text { adequacy and } \\
\text { professional training }\end{array}$} & \multirow[t]{4}{*}{$\begin{array}{c}\text { Management of risk } \\
\text { factors for hearing loss }\end{array}$} & Identification of risk factors & 35 & 94.5 \\
\hline & & Association of risk factors with developmental milestones & 37 & 100.0 \\
\hline & & $\begin{array}{l}\text { Registration of hearing developmental milestones on form/ } \\
\text { medical record/child health booklet }\end{array}$ & 37 & 100.0 \\
\hline & & $\begin{array}{l}\text { Use of instruments and/or strategies for emission of sound } \\
\text { (clapping, snapping fingers, talking, making noise with some } \\
\text { instrument as keys, paper, ruler, pen, etc.) }\end{array}$ & 37 & 100.0 \\
\hline & \multirow[t]{10}{*}{$\begin{array}{l}\text { Monitoring of hearing } \\
\text { developmental } \\
\text { milestones and conduct }\end{array}$} & Direct hearing developmental milestones & 37 & 100.0 \\
\hline & & Indirect hearing developmental milestones & 37 & 100.0 \\
\hline & & Start of hearing screening in the 1st month of life & 28 & 75.6 \\
\hline & & $\begin{array}{c}\text { Universal Newborn Hearing Screening (UNHS) - qualified } \\
\text { audiologist }\end{array}$ & 32 & 86.4 \\
\hline & & Ideal age for the diagnosis of hearing loss & 12 & 32.4 \\
\hline & & Ideal age for the intervention/rehabilitation of hearing loss & 4 & 10.8 \\
\hline & & Resolution of case 1 & 33 & 89.1 \\
\hline & & Resolution of case 2 & 15 & 40.5 \\
\hline & & Resolution of case 3 & 35 & 94.5 \\
\hline & & Resolution of case 4 & 37 & 100.0 \\
\hline \multirow{3}{*}{ Professional training } & \multirow[t]{3}{*}{ Educational practices } & $\begin{array}{l}\text { Educational activities on child health hearing for the } \\
\text { community }\end{array}$ & 8 & 21.6 \\
\hline & & Discipline with content related to child health hearing & 8 & 21.6 \\
\hline & & Courses and/or trainings on child hearing health care & 3 & 8.1 \\
\hline
\end{tabular}


Table 3 - Assessment methods and types of forms used for recording the hearing developmental milestones during child care - Recife, 2013

\begin{tabular}{lcc}
\hline Assessment methods & N & \% \\
\hline Percussion instruments & 2 & 5.4 \\
Stimuli for the emission of sound & 24 & 64.9 \\
Percussion instruments and stimuli for the emission of sound & 11 & 29.7 \\
Types of forms for registration & & \\
Medical records & 13 & 35.1 \\
Medical records and child registration form & 17 & 46.0 \\
Medical records, child registration form, and child health booklet & 4 & 10.8 \\
Medical records and child health booklet & 3 & 8.1 \\
\hline
\end{tabular}

The highest mean scores related to the nursing practice in child hearing health care were in the group of female professionals ( $\bar{X}=75.0$ points) under 40 years of age ( $\bar{X}=75.6$ points), with $11-20$ years since graduation ( $\mathrm{X}=76.5$ points), with a master title ( $\mathrm{X}=76.9$ points), six to ten years of professional experience ( $\bar{X}=75.6$ points), and two worked in the micro area 2 ( $\bar{X}=74.9$ points). Only the male and female groups of nurses showed a statistically significant difference between the mean scores ( $p$-value $=0.018)$ (Table 4$)$.
There was no statistically significant difference in the mean scores related to the performance of nurses in identifying the ideal age for the initial assessment, diagnosis and intervention of hearing loss. However, the group of professionals that gave correct answers to the indicators showed an average score greater than or equal to the group that gave wrong answers. The adequacy of the nurses' practice in both aspects (physical structure and process) was considered adequate in 20 cases $(54.1 \%)$ and partially adequate in 17 cases (45.9\%). The average score was 74.5 points $(61.2-85.6 / \mathrm{SD}=$ 4.7) and the p-value of 0.622 .

Table 4 - Score of the nurses' practice in child hearing health care, according to demographic and professional variables - Recife, 2013

\begin{tabular}{|c|c|c|c|c|c|c|c|}
\hline Evaluated factor & Minimum & Maximum & Mean & Median & $\begin{array}{l}\text { Standard } \\
\text { deviation }\end{array}$ & CI $(95 \%)$ & p-value \\
\hline \multicolumn{8}{|l|}{ Gender } \\
\hline Male & 61.2 & 72.5 & 66.8 & 66.8 & 8.0 & - & $0.018^{1}$ \\
\hline Female & 63.8 & 85.6 & 75.0 & 75.0 & 4.3 & $73.5-76.4$ & \\
\hline \multicolumn{8}{|l|}{ Age (years) } \\
\hline$<40$ & 63.8 & 85.6 & 75.6 & 75.0 & 5.1 & $73.1-78.1$ & $0.159^{1}$ \\
\hline$\geq 40$ & 61.2 & 81.2 & 73.4 & 74.4 & 4.2 & $71.3-75.5$ & \\
\hline \multicolumn{8}{|c|}{ Time since graduation (years) } \\
\hline$\leq 10$ & 61.2 & 85.6 & 73.5 & 73.7 & 6.6 & $69.5-77.5$ & $0.246^{2}$ \\
\hline $11-20$ & 70.6 & 81.8 & 76.5 & 76.8 & 3.9 & $73.9-79.2$ & \\
\hline$>20$ & 70.6 & 77.4 & 73.8 & 75.0 & 2.6 & $72.2-75.4$ & \\
\hline \multicolumn{8}{|l|}{ Academic title } \\
\hline Specialization & 63.8 & 85.6 & 74.6 & 75.0 & 4.6 & $72.9-76.4$ & $0.662^{2}$ \\
\hline Residence & 61.2 & 81.8 & 73.7 & 75.0 & 6.2 & $68.0-79.4$ & \\
\hline Master & 76.9 & 76.9 & 76.9 & - & - & - & \\
\hline \multicolumn{8}{|c|}{ Operating time (years) } \\
\hline $0-5$ & 61.2 & 76.9 & 72.3 & 75.0 & 5.9 & $67.8-76.8$ & $0.262^{2}$ \\
\hline $6-10$ & 70.6 & 85.6 & 75.6 & 73.7 & 5.4 & $72.0-79.3$ & \\
\hline$>10$ & 70.6 & 81.8 & 75.0 & 75.6 & 3.5 & $73.2-76.8$ & \\
\hline \multicolumn{8}{|c|}{ Micro area of practice } \\
\hline 1 & 63.8 & 83.1 & 74.1 & 74.4 & 4.9 & $71.3-76.9$ & $0.926^{2}$ \\
\hline 2 & 70.6 & 78.1 & 74.9 & 75.3 & 2.7 & $72.7-77.1$ & \\
\hline 3 & 61.2 & 85.6 & 74.7 & 75.0 & 5.8 & $71.5-77.9$ & \\
\hline
\end{tabular}

${ }^{1}$ Student's $t$ test-. ${ }^{2}$ Anova. It was not possible to calculate the confidence interval due to the small number of observations of the male gender.

\section{DISCUSSION}

In the evaluation of the physical structure, it was shown that in all family health units (FHU) there are rooms for consultation, tables, chairs, bed, gurney or table for exams. Despite adequacy of physical space, it was observed that some FHU needed repairs for better accommodation of professionals and users, coinciding with a study carried out in the municipalities of the state of Bahia, which showed precarious conditions of conservation and hygiene in most FHU, with the presence of leaks and poor lighting ${ }^{(16)}$. This is a limitation identified by the Ministry of Health in 2008, which found a significant number of FHU with inadequate or poorly improvised physical structure, despite the improvement in the quality of services provided ${ }^{(17)}$. 
Regarding the necessary material for the nurse practice in child care, it was found that all the FHU offer a medical record and the child health booklet in different versions (2007 and 2009) for the registration of consultations. However, only the child health booklet, version 2009 , presented the surveillance instrument of child development with guidance for the decision-making of professionals $^{(11)}$.

During the assessment of hearing developmental milestones of the child, the nurses use instruments for emission of sounds, such as a rattle, bell, and others. However, most of the FHU do not offer these instruments, demonstrating that their absence may hinder the working process of professionals. In this perspective, the majority of nurses resorts to stimuli for the emission of sound during the assessment, such as clapping, snapping fingers and talking, partially agreeing with the guidelines described in the surveillance instrument of development $^{(11-12)}$.

But although these adjustments can help the work process of nursing professionals directed to child hearing health, they are not always considered appropriate to assess auditory development ${ }^{(18)}$. It is known that the material resources provide support to the assistances and their absence may cause errors or inaccuracies in the work process of nurses.

The fact that a minority of FHU provides informational materials aimed at child hearing health reassures the necessity of the municipal health management providing such material to assist professionals and users in educational actions. The evidenced informational materials addressed the importance of the UNHS. According to the Ministry of Health, the availability of these materials qualifies the assistance of primary health care and generates impact in the local system ${ }^{(19)}$.

In evaluating dimension of management of risk factors for hearing loss indicated that most nurses the work process of nurses, the sub reported at least two risk factors advocated by the Joint Committee on Infant Hearing $^{(5-6)}$. The risk factors can emerge from the pre, throughout, and in the post-natal periods. The most described in this study were congenital and postnatal infections, heredity or familiar antecedent, trauma in ear and recurrent otitis media. It is important that nurses recognize the risk factors for hearing loss in infants in order to promote appropriate follow-up regarding the developmental milestones of hearing and language, to strengthen their professional practice in child care consultations and thus prevent hearing loss.

In this same sub dimension, it was found that all nurses recognize the association between the child developmental milestones and the risk factors for hearing loss. This is a favorable fact for the work process of these professionals, demonstrating the importance of deve- lopmental surveillance as one of the systematic actions carried out during the child care consultation. The actions taken in child care consultation aim at identifying problems, making diagnoses and nursing interventions that can aid in the early detection of hearing loss ${ }^{(18)}$.

The distinction of the hearing developmental milestones, that was directly or indirectly connected with hearing and language by the nurses, becomes essential for the early identification of hearing loss, since a large part of language acquisition occurs during the first two years of life ${ }^{(3)}$. It is pertinent to ask about the training on the child developmental milestones that these nurses had during graduation, including hearing, since the institutions should train them to meet the health needs of children in their specialties ${ }^{(20)}$.

Proper nursing practice includes not only the assessment of hearing developmental milestones, but the record of information gathered during the consultation. In all FHU, at least one of the required forms was available and all practitioners affirmed to register the absence of any hearing milestone, when detected. Registration is essential as a source of information to improve the quality of the supplied actions. The forms available in more than $40 \%$ of the FHU were the medical record and child record, followed by the medical record only. Most of these professionals did not record the assessment of the child's development in the child health booklet, which may be the result of poor training on the implementation of the surveillance instrument of child development ${ }^{(11-12)}$.

Despite the satisfactory identification of the hearing developmental milestones by these professionals, were identified low percentages of discernment of ideal age for diagnosis and intervention/rehabilitation of hearing loss, disagreeing with the Joint guidelines that recommend the diagnosis before three months of life and the promotion of intervention/rehabilitation before six months ${ }^{(6)}$.

The improvement of the diagnostic assistance and specialized therapy to people with or without risk of hearing loss through the provision of screening and hearing monitoring of neonates, children in preschool and school is essential, as well as the permanent education of health professionals ${ }^{(8)}$. When investigating the ideal time for the initial hearing assessment of newborns, called UNHS, OAE test ('teste da orelhinha'), most nurses confirmed it was done in the first month of life for detection of hearing loss, in accordance with the Law 12.303 of $02 / 08 / 2010$ on mandatory screening test in all newborns born in hospitals, along with the recommendations of the Multidisciplinary Committee on Hearing Health (Comusa - Comitê Multiprofissional em Saúde Auditiva) that recommends the screening until the first month of life in neonates, or the extension until the third month of life in specific situations ${ }^{(7,21)}$.

According to data obtained in the surveillance instrument of development, the conduct of nurses on the
Child hearing health: practice of the Family Health Strategy nurses

Azevedo SB, Leal LP, Lima MLLT, Griz SMS 
clinical cases was considered appropriate in the context of primary health care ${ }^{(11-12,22)}$. In case 1 , predominated the referral of infants to specialized professionals due to the absence of hearing developmental milestones of the previous age range, and the presence of risk factors for hearing loss without doing the screening test (UNHS).

In case 2, only part of the nurses adopted the correct conduct in infants with normal development and risk factor for hearing loss, reinforcing the need for training or courses related to child hearing health, especially about the risk factors for hearing loss ${ }^{(12)}$.

In case 3, the majority of nurses had the proper conduct with an eight-month old infant with normal hearing development for age, guiding the follow-up according to the schedule of routine recommended by the Ministry of Health (every two months) or by the protocol of the municipality (monthly visits up to the first year of life). In 2007 , a study found that $79 \%$ of nurses recognized the main developmental milestones expected in the first year of life, in which hearing and language are included ${ }^{(23)}$.

In case 4 , which indicates a probable developmental delay with possible hearing impairment, all nurses proceeded to referral of the infant to neuropsychomotor evaluation with other professionals. This indicates that these nurses correlated the absence of the hearing milestone with the various risk factors, and the UNHS results suggestive of hearing loss. The infant with probable developmental delay due to hearing loss should be referred to ENT and audiological constant monitoring ${ }^{(22)}$.

In the dimension of professional training, only a few nurses obtained information on child hearing health during undergraduate and post-graduate courses, courses or training, which proves the need for permanent education and the inclusion of information about child hearing health in undergraduate courses. According to the National Curriculum Guidelines (DCN - Diretrizes Curriculares Nacionais) ${ }^{(24)}$, nurses must continually learn both in training and in practice, through permanent education. Upon graduation, they need to know and act on the problems of health and disease prevalent in the country and in their region of practice, in order to develop actions for prevention of diseases/conditions, promotion, protection and rehabilitation of health. Another aspect to be ratified during graduation is the movement of curricular changes in nursing, based on interdisciplinarity, to meet the demands in face of the health-disease complex process, aiming at completeness of the system and the propositions of the National Curriculum Guidelines ${ }^{(20)}$.

Despite the predominance of nurses specialized in family health or public health, when directing knowledge for child hearing health, around $70 \%$ affirmed they had not received any specific information. It is important that these professionals are constantly prepared for their practice within the FHS, with technical-scientific rigor, acting in a critical, reflective, general and humanistic way in health care under the logic of the SUS (unified health system) $)^{(25)}$.

This limitation in professional training influences the work process, because when checking the sub dimension of 'educational actions' for the community, it was found that few professionals carried out this activity. This fact negatively implies on assessing the practice of nurses due to the importance of health education for the community as a means of prevention and early detection of hearing loss. Despite the reorientation in the field of theoretical and methodological reflections of the health education, the adoption of educational activities directed to child hearing health was not evident in the services, with challenges appearing in the nursing training directed to health education in primary care ${ }^{(26)}$.

The evaluated aspects related to the structure of FHU and the work process of nurses, in line with the matrix of indicators, obtained the final classification as adequate and partially adequate, showing that the indicators were met. The results of this study, regarding the physical structure/needed materials of the FHU for nursing consultation in child care coincided with a study carried out in 2010, in São Paulo, which was satisfactory when assessing this same aspect ${ }^{(27)}$.

Regarding the process, it is important to note that, although the recognition of the hearing developmental milestones and the conduct adopted by nurses were adequate, there is no practice of applying the surveillance instrument of child development. The lack of application of this instrument can hinder the work process of nurses in monitoring the growth and development of children, as demonstrated in a study carried out in a municipality of the state of Paraíba ${ }^{(28)}$, confirming the necessity of permanent education in the training and practice of nurses, with disciplines or courses/training aimed at the application of this instrument.

In this context, the provision of courses/trainings for FHS nurses related to the surveillance of child development is essential for improving the quality of the actions developed in child care, as demonstrated in a study that obtained satisfactory results for the transformation of the practice of trained professionals ${ }^{(29)}$. The proper practice of FHS nurses strengthens their responsibility in the development surveillance of neonates and infants in their first year of life as part of a team of specialized professionals (pediatrician, neuropediatrician, ENT, etc) ${ }^{(30)}$.

In this study, the criteria evaluation was characterized as a critical-reflective and systematic procedure on the practices and work processes of nurses in health services $^{(19)}$. However, when measuring the performance of an intervention, the normative assessment is limited to pre-established criteria, which may cause gaps to be investigated in other evaluation studies. 


\section{CONCLUSION}

The evaluation of the work process of FHS nurses was adequate, although there are some limitations regarding the structure and process. The proper practice of these professionals in the care to child hearing health benefits the developing neonate and infant, preventing hearing loss.

On the physical structure, the less evident indicators were the informational materials targeted to child hearing health and the percussion instruments for the assessment of hearing developmental milestones.

The less evident indicators regarding the process were the ideal age for diagnosis, intervention and rehabilitation of hearing loss, and the conduct in relation to case 2 (infants with a risk factor for hearing loss with normal development). It is pertinent to relate these indicators with the limitation in the dimension of professional training observed in this study.

\section{REFERENCES}

1. Organización Mundial de la Salud (OMS). Sordera y pérdida de la audición [Internet]. Ginebra; 2013 [citado 2013 set. 18]. Disponible en: http://www.who.int/mediacentre/factsheets/ fs300/es/index.html

2. Instituto Brasileiro de Geografia e Estatística (IBGE). Censo demográfico 2010. [Internet]. Rio de Janeiro; 2012 [citado 2013 set. 02]. Disponível em: http://ftp.ibge.gov.br/Censos/ Censo_Demografico_2010/Resultados_Gerais_da_Amostra/ resultados_gerais_amostra.pdf

3. Trainor LJ. Utilizando eletroencefalografia (EEG) para medir maturação do córtex auditivo em bebês: processando frequência, duração e localização do som. In: Tremblay RE, Boivin $M$, Peters RDV. Enciclopédia sobre o desenvolvimento na primeira infância. Montreal, Quebec: Centre of Excellence for Early Childhood Development e Strategic Knowledge Cluster on Early Child Development; 2013. p.1-6.

4. Azevedo MF. Triagem auditiva neonatal. In: Ferreira LP, BefiLopes DM, Limongi SCO, organizadores. Tratado de fonoaudiologia. São Paulo: Roca; 2004. p. 604-16.

5. Joint Committee on Infant Hearing. Year 2007 position statement: principles and Guidelines for Early Hearing Detection and Intervention Programs. Pediatrics. [Internet]. 2007 [cited 2013 Sept 20];120(4):898-921. Available from: http://pediatrics.aappublications.org/content/120/4/898.long

6. Joint Committee on Infant Hearing. Year 2000 Position statement: principles and Guidelines for Early Detection and Intervention Programs. Pediatrics [Internet]. 2000 [cited 2012 Sept 20];106(4):798-817. Available from: http://pediatrics.aappublications.org/content/106/4/798.long
The promotion of educational actions focused on child hearing health was little emphasized by the professionals, what resumes the need for courses and/or trainings aimed at complementary education to improve attention to infant hearing health within the primary care. It is necessary that nurses show the technical-scientific domain acquired in their training in order to perform their duties with quality.

Conducting periodic assessments is essential to support both the FHS nurses in their work process, as the management for implementing effective measures in the quality improvement of the care to child hearing health. The normative assessment of the structure and process brought benefits for both nurses as for the current management, allowing that new evaluation studies are carried out in the future to identify changes within the care to child hearing health and its effects for the involved actors.
7. Brasil. Lei n. 12.303, de 02 de agosto de 2010. Dispõe sobre a obrigatoriedade de realização do exame denominado Emissões Otoacústicas Evocadas [Internet]. Brasília; 2010 [citado 2013 jan. 16]. Disponível em: http://www.planalto.gov.br/ ccivil_03/_Ato2007-2010/2010/Lei/L12303.htm

8. Brasil. Ministério da Saúde. Portaria n. 587, de 07 de outubro de 2004. Política Nacional de Atenção à Saúde Auditiva [Internet]. Brasília; 2004 [citado 2012 abr. 12]. Disponível em: http:// dtr2001.saude.gov.br/sas/PORTARIAS/Port2004/PT-587.htm

9. Brasil. Ministério da Saúde. Portaria n. 2073, de 28 de setembro de 2004. Instituí a Política Nacional de Atenção à Saúde Auditiva [Internet]. Brasília; 2004 [citado 2012 maio 12]. Disponível em: http://dtr2001.saude.gov.br/sas/PORTARIAS/ Port2004/GM/GM-2073.htm

10. Brasil. Ministério da Saúde. Política Nacional da Atenção Básica [Internet]. Brasília; 2012 [citado 2012 set. 03]. Disponível em: http://189.28.128.100/dab/docs/publicacoes/geral/pnab.pdf

11. Brasil. Ministério da Saúde. Caderneta de Saúde da Criança - Passaporte da Cidadania. 7a ed. Brasília: DF; 2011.

12. Brasil. Ministério da Saúde. Saúde da criança: crescimento e desenvolvimento. [Internet]. Brasília; 2012 [citado 2012 set. 17]. Disponível em: http://bvsms.saude.gov.br/bvs/publicacoes/crescimento_desenvolvimento.pdf

13. Russo, ICP, Santos, TMM. Audiologia infantil. 4a ed. São Paulo: Cortez; 2009.
Child hearing health: practice of the Family Health Strategy nurses

Azevedo SB, Leal LP, Lima MLLT, Griz SMS 
14. Samico I, Felisberto E, Figueiró AC, Frias PG, organizadores. Avaliação em saúde: bases conceituais e operacionais. Rio de Janeiro: MedBook; 2010.

15. Brasil. Ministério da Saúde; Organização Pan-Americana de Saúde. Manual AIDPI Neonatal: quadro de procedimentos. 3a ed. Brasília; 2012.

16. Moura BLA, Cunha RC, Fonseca ACF, Aquino R, Medina MG, Vilasbôas ALQ, et al. Atenção primária à saúde: estrutura das unidades como componente da atenção à saúde. Rev Bras Saúde Mater Infant. 2010;10 Supl.1:S69-S81.

17. Brasil. Ministério da Saúde. Manual de estrutura física das unidades básicas de saúde: saúde da família. 2ª ed. Brasília; 2008.

18. Campos RMC, Ribeiro CA, Silva CV, Saparolli ECL. Nursing consultation in child care: the experience of nurses in the FamiIy Health Strategy. Rev Esc Enferm USP. 2011;45(3):566-74.

19. Brasil. Ministério da Saúde; Secretaria de Atenção à Saúde. Avaliação normativa do Programa Saúde da Família no Brasil: monitoramento da implantação e funcionamento das Equipes de Saúde da Família: 2001-2002 [Internet]. Brasília; 2004. [citado 2012 dez 18]. Disponível em: http://189.28.128.100/ dab/docs/publicacoes/geral/avaliacao_normativa_psf.pdf

20. Almeida $A H$, Soares $C B$. Health education: analysis of its teaching in undergraduate nursing courses. Rev Latino Am Enfermagem. 2011;19(3):614-21.

21. Lewis DR, Marone SAM, Mendes BCA, Cruz OLM, Nóbrega M. Comitê multiprofissional em saúde auditiva: COMUSA. Braz J Otorhinolaryngol. 2010;76 (1):121-8.

22. Brasil. Ministério da Saúde. Diretrizes de Atenção da Triagem Auditiva Neonatal. [Internet]. Brasília; 2012 [citado 2013 dez. 18]. Disponível em: http://bvsms.saude.gov.br/bvs/publicacoes/diretrizes_atencao_triagem_auditiva_neonatal.pdf
23. Saparolli ECL, Adami NP. Avaliação da qualidade da consulta de enfermagem à criança no Programa de Saúde da Família. Acta Paul Enferm. 2007;20(1):55-61.

24. Brasil. Ministério da Educação. Resolução CNE/CES n. 3, de 7 de novembro de 2001. Institui Diretrizes Curriculares Nacionais do Curso de Graduação em Enfermagem. [Internet]. Brasília; 2001 [citado 2014 jan. 2]. Disponível em: http:// portal.mec.gov.br/cne/arquivos/pdf/CES03.pdf

25. Costa RKS, Miranda FAN. O enfermeiro e a estratégia saúde da família: contribuição para a mudança do modelo assistencial. Rev RENE. 2008;9(2):120-8.

26. Silva CMC, Meneghim MC, Pereira AC, Mialhe FL. Educação em saúde: uma reflexão histórica de suas práticas. Ciênc Saúde Coletiva. 2010;15(5):2539-50.

27. Saparolli ECL, Adami NP. Evaluation of nursing consultation structure for children in primary health care. Rev Esc Enferm USP. 2010;44(1):92-8.

28. Assis WD, Collet N, Reichert APS, Sá LD. Processo de trabaIho da enfermeira que atua em puericultura nas Unidades de Saúde da Família. Rev Bras Enferm. 2011;64(1):38-46.

29. Reichert APS, Eickmann SH, Lima MC. Assessment of the implementation of an educational intervention on developmental surveillance with nurses. Rev Esc Enferm USP. 2012;46(5):1049-56.

30. Kuo AA, Inkelas $M$, Maidenberg $M$, Lotstein DS, Sansão KM, Halfon N. Pediatricians' roles in the provision of developmental services: an international study. J Dev Behav Pediatr. 2009;30(4):331-9. 